\title{
Why I Stopped Believing in Customary International Law
}

\author{
Daniel H. JOYNER*
}

University of Alabama School of Law, the United States of America djoyner@law.ua.edu

\begin{abstract}
There has been a recent proliferation of scholarship on the development, identification, and determination of customary international law [CIL]. Much of this has focused on explication of the theoretical and practical problems inherent in the modern use of CIL as a source of international law. However, there are influential voices who argue that CIL nevertheless continues to play a necessary role in the international legal system, and that many of the problems that have been identified are exaggerated. This paper maintains that the problems which have been identified in the processes of identification and determination of CIL are of such a serious and institutionalized nature as to produce a presumptive distrust of any statement about what is or is not CIL. It argues that the process of identifying and authoritatively determining CIL must evolve to more objectively evidence the positive assent of states to the making of customary rules.
\end{abstract}

Every Autumn I teach my course on public international law. And every year, during the second class session, I teach the sources of international law. Together we dutifully look to the Statute of the International Court of Justice [ICJ], Article 38, and examine the recitation of the sources there. My explanation of treaties as a source of international law tends to go pretty smoothly. After all, treaties are a lot like contracts among states-they're negotiated and written down, and states either agree to them or not. Students can therefore pretty easily process the idea of treaties as a source of international legal obligation.

But then when I start explaining customary international law [CIL] to them, all of a sudden there's a lot more note-taking, and fewer heads nodding in understanding. We talk about the orthodox two-element formula for the development of a rule of customary law, i.e. the combined presence of state practice and opinio juris. I then give the traditional explanation of what counts as state practice, how we determine the presence of opinio juris, what kinds of evidence suffice to demonstrate both, and the standards of sufficiency for each kind of evidence. I have to use statements like

Elton B. Stephens Professor of Law, University of Alabama School of Law. I would like to thank Jean d'Aspremont and Iain Scobbie for their thoughtful discussion of these topics, and comments on earlier drafts. 
"generally speaking", "typically", and "most of the time" a lot. Then I ask them if there are any questions. There seldom are.

What I'm hoping at this point, of course, is that they'll believe that what I'm teaching them is real. I hope that they'll accept custom as a source for the creation of international legal obligation, along with treaties. Although, in actuality, I have offered them fairly little on which to base such a belief, except my say-so. That's because by far most of the material I can give them to explain the mechanics of how this rather ethereal concept is in fact evidenced, identified, and authoritatively determined, comes from a few snippets of ICJ cases, and from other law professors' writings about it. I really just have to hope they'll accept the whole thing as a matter of faith so that we can move on.

And I suppose that's what I've done myself, in fact, over my twenty years or so of studying international law-i.e. accepted as a matter of faith that custom is a source of international law, and that it can in fact be identified through an examination of evidence as against the two-element formula. That it can be both conceptually and practically supported as a means for generating international legal obligation. Perhaps fortunately, my own faith in this idea has seldom been seriously challenged because the area of law that I have written most in is primarily based on an established web of treaties and international organizations, with CIL playing only a marginal role. But on the occasions when I have had to seriously think about how CIL develops, is authoritatively identified and determined, and is ultimately used in the international legal system, I've experienced a growing concern about it for some time.

So over the past couple of years, I've tried to read as widely as I could in the scholarly literature on CIL development, identification, and determination. And such work hasn't been difficult to find. Particularly due to the International Law Commission's [ILC's] work programme on this topic, which it began in 20I 2, there has been a recent proliferation of scholarly treatment. ${ }^{\mathrm{I}}$ Much of this scholarship has focused on

I. See Curtis A. BRADLEY, ed., Custom's Future: International Law in a Changing World (Cambridge: Cambridge University Press, 20I6); Jean D'ASPREMONT, ed., Participants in the International Legal System: Multiple Perspectives on Non-State Actors in International Law (New York: Routledge, 20I I); Laszlo BLUTMAN, “Conceptual Confusion and Methodological Deficiencies: Some Ways that Theories on Customary International Law Fail” (2OI4) 25 European Journal of International Law 529; Laurence HELFER and Ingrid WUERTH, "Customary International Law: An Instrument Choice Perspective" (2016) 37 Michigan Journal of International Law; Jean D’ASPREMONT, "Expansionism and the Sources of International Human Rights Law" (2016) 46 Israel Yearbook of International Human Rights 223; Jean D'ASPREMONT, “The Decay of Modern Customary International Law in Spite of Scholarly Heroism" in Giuliana Ziccardi CAPALDO, ed., Global Community: Yearbook of International Law and Jurisprudence (Oxford: Oxford University Press, 201 5); Niels PETERSEN. "The International Court of Justice and the Judicial Politics of Identifying Customary International Law" (20I7) 28 European Journal of International Law 357; Stefan TALMON, "Determining Customary International Law: The ICJ's Methodology Between Induction, Deduction and Assertion" (2015) 26 European Journal of International Law 4I7; Christian TAMS, "Meta-Custom and the Court: A Study in Judicial Law-Making" (2015) I 4 Law \& Practice of International Courts and Tribunals 5I; Brian D. LEPARD, Customary International Law: A New Theory with Practical Applications (Cambridge: Cambridge University Press, 20I0); Pierre-Hueges VERDIER and Erik VOETEN, "Precedent, Custom and Change in Customary International Law: An Explanatory Theory" (2014) Io8 American Journal of International Law 389 ; Roozbeh (Rudy) B. BAKER, "Customary International Law in the 2 Ist Century: Old Challenges and New Debates" (2010) 2I European Journal of International Law I73; Rudolf GEIGER, "Customary International Law in the Jurisprudence of the International Court of Justice: A Critical Appraisal" in Ulrich FASTENRATH et al., eds., From Bilateralism to Community Interest: Essays in Honour of Bruno Simma (Oxford: Oxford University Press, 20I I); G.I. HERNÁNDEZ, The International Court of Justice and the Judicial Function (Oxford: Oxford University Press, 20I4); Stephen J. CHOI and Mitu GULATI, 
explication of the theoretical and practical problems inherent in the modern use of CIL as a source of international law. This recent work builds on strains of critique of CIL that go back decades. ${ }^{2}$

At the same time, there are still influential voices who argue that, notwithstanding these problems, some of which they contend are overstated, CIL nevertheless continues to play a practically useful and necessary role in the international legal system, and that there is nothing fundamentally wrong with the orthodox process for identifying CIL. ${ }^{3}$ This view has been adopted by the ILC's ongoing work programme, which has accepted the continued validity of the orthodox view of the two-element process for CIL determination. ${ }^{4}$

On balance, in my reading and consideration, I have become persuaded that the problems which have been identified in the processes of identification and determination of CIL, and their implication for the international legal system, are of such a serious and institutionalized nature that I now presumptively distrust any statement about what is or is not a rule of CIL. Basically, as I've learned more about how CIL is used in practice, I've stopped believing in CIL as a supportable source for the creation of international legal obligation. I have become convinced that if CIL is going to retain its place as a source of international legal obligation, the process of identifying and authoritatively determining CIL must evolve to more objectively evidence the positive assent of states to the making of customary rules.

\section{CIL AND ITS SEVERAL IDENTIFIERS}

The orthodox view of how CIL works is deceptively simple. One looks at the record of state actions and statements and if something like a supermajority of states have engaged in the same or similar practice with regard to some normative principle of international interaction, and have engaged in this practice for a long time with little inconsistency, and if they appear to do this because they think it is legally obligatory for them to do so (or at least that doing so is in harmony with existing law), then those two elements of state practice and opinio juris (i.e. one objective element and one subjective element) evidence that states have accepted this principle as a rule of customary international law. ${ }^{5}$ If this is determined to be the case, the rule of customary law

“Customary International Law: How Do Courts Do It?” in Bradley, Custom's Future: International Law in a Changing World; Alberto ALVAREZ-JIMENEZ, "Methods for the Identification of Customary International Law in the International Court of Justice's Jurisprudence: 2000-2009" (20I I) 60 International and Comparative Law Quarterly 68I.

2. See David J. BEDERMAN, Custom as a Source of Law (Cambridge: Cambridge University Press, 20I0); B.S. CHIMNI, "Customary International Law: A Third World Perspective" (2018) II2 American Journal of International Law I.

3. See Michael WOOD, “Custom's Bright Future: The Continuing Importance of Customary International Law” in Bradley, supra note I.

4. See Michael WOOD, First Report on Formation and Evidence of Customary International Law, UN Doc. A/ CN.4/663 (2013); Second Report on Identification of Customary International Law, UN Doc. A/ CN.4/672 (20I4); Third Report on Identification of Customary International Law, UN Doc. A/CN.4/ 682 (20I5).

5. See James CRAWFORD, Brownlie's Principles of Public International Law, 7th ed. (Cambridge: Cambridge University Press, 2008). 
becomes a legal obligation for all states, even for those who did not participate in the rule's creation, subject only to the caveat that states who persistently object to the creation of the rule throughout its development are exempt from this obligation. Again, the idea is that states can agree on rules governing their behaviour through their customary conduct and sense of legal obligation attaching to it, without having to put this obligation into writing. Proponents of the utility of CIL argue that such a source of legal obligation has always been, and continues to be, a necessary component of the international legal system for a number of reasons. These include its role as a source for overarching systemic or secondary rules for the international legal system, its role in addressing issue areas not covered by an existing treaty including technologically new or dynamic issue areas, its role in filling in gaps in existing treaty coverage, and its role in creating parallel obligations to those included in the provisions of broadlysubscribed-to treaties in order to make those treaty provisions binding upon all states, including treaty outliers. ${ }^{6}$

The problematic aspects of this concept of a legal source, however, become apparent pretty quickly upon closer examination. With CIL, the devil really is in the details. How many states does it take to manifest their state practice in support of a new rule of CIL? How long must this practice have continued? What kind of state practice counts? How much inconsistent state practice can be tolerated? Does the practice of some states matter more than others?

The questions concerning the subjective element of opinio juris are even more problematic. What does it mean for a state to act under a sense of legal obligation? Do they actually have to think that what they're doing is required by existing law? And what does it mean for a state to "think" this? If so, isn't there a real chicken and egg problem there-i.e. what did the first state who acted in this way think? Were they just deluding themselves? And how are we supposed to know what states are thinking about why they are acting in a certain way? They seldom discuss their subjective understanding of their legal obligations. So what kinds of evidence will count in manifesting that opinio juris? How much of that evidence is required, and of how many states, before we can say that the subjective element is satisfied?

When I teach the principle of customary international law to my classes, and the brighter students start to ask these questions, I tell them that, as a practical matter, international lawyers look to several different law-identifying agencies to sort through what is CIL and what is not. The first and most important of these is international courts, including the ICJ.

\section{A. International Courts}

So how do international courts sort out, or identify, the existence of a rule of CIL? This question has actually been one of the most fascinating subjects of the recent wave of scholarship on CIL. A number of authors have conducted empirical studies of cases

6. See Wood, supra note 3 ; Detlev F. VAGTS, "International Relations Looks at Customary International Law: A Traditionalist's Defence" (2004) I 5 European Journal of International Law IO3 I; Tullio TREVES, “Customary International Law” in Rudiger WOLFRUM, ed., The Max Planck Encyclopedia of Public International Law (Oxford: Oxford University Press, 2009). 
decided by international courts, including the ICJ, international criminal tribunals, and others. What they have found is that these august international judicial bodies typically do not display systematic, rigorous analysis of evidence falling under the framework of the orthodox two-element test. Stefan Talmon, for example, has criticized the ICJ itself for engaging in a deductive and assertive, as opposed to a properly inductive, methodology when considering evidence of CIL, and for thereby engaging in judicial legislation-although he also observes the perceived need for the Court to take this approach. As he explains:

In a majority of cases the Court has not examined, whatever it may say on the matter, the practice and opinio juris of States, but has simply asserted the rules which it applies. This methodological approach has been criticized even by its own members. But assertion is not always merely a convenient methodological shortcut. There are situations where the inductive and deductive methods will not allow the Court to fulfil its normal judicial function of determining the applicable rules of customary international law because induction is virtually impossible, or because there are no relevant general rules or principles from which to deduce the applicable law. Judicial assertion is the price States have to pay for the Court not to declare an epistemological non liquet. ${ }^{7}$

In another such study, involving a broader range of international judicial bodies, Stephen Choi and Mitu Gulati found that:

Courts in this area, it turns out, do not neatly separate out the evidence that they look at in terms of saying X piece of evidence helped persuade them on prong one and Y piece of evidence helped persuade them on prong two. Instead they tend to bundle all the evidence into a single discussion and then assert whether the two-prong test is satisfied (and sometimes they do not even mention the two-prong test). ${ }^{8}$

Choi and Gulati are less sympathetic than Talmon to considerations regarding the judicial function and the need for CIL to serve a jurisprudential gap-filling role:

The data suggest that international courts do not come anywhere close to engaging in the type of analysis the officially stated two-part rule for the evolution of CIL sets up. Instead, as best we can tell, courts analyzing CIL-whether they find it or not-are generally engaged in a forward-looking or aspirational exercise. ${ }^{9}$

These studies have helped to shed light on how international courts in fact go about looking for CIL, what kinds of evidence they think are relevant to that determination, and what standards they actually apply to that evidence. And, as the studies show, international courts cannot be said to be exemplary in their application of the orthodox two-element approach to CIL identification, which remains the orthodoxy in all of the textbooks on international law, and which has been reaffirmed through the recent work of the ILC.

\footnotetext{
7. Talmon, supra note I at $4 \mathrm{II}$.

8. Choi and Gulati, supra note I at I25.

9. Ibid., at 147 .
} 
This fact alone is extremely problematic. Inasmuch as my standard answer to my students is that their methodological questions on identifying and determining CIL in practice can be answered by reference to how international courts go about this exercise-which really ought to be a sound answer to those questions-the fact that international courts demonstrably do not apply the principles that I am teaching them as orthodox, seriously decreases my own confidence in that answer.

\section{B. The International Law Commission}

The second commonly referenced law-identifying agency is the International Law Commission. The ILC was established by the United Nations General Assembly in I 947 as a standing group of international law experts, nominated by states and approved for office by the General Assembly itself. The ILC's mandate was given to it by the General Assembly in its founding Statute as follows: "The International Law Commission shall have for its object the promotion of the progressive development of international law and its codification."

The ILC has always pursued its mandate with an underlying tension, evident in the mandate itself. Note that it is explicitly mandated to promote both the "progressive development" of international law, and its "codification". ${ }^{\text {Iо }}$ The first head of this mandate is normative, the second is descriptive. Or, in other words, the first head looks to the development of the lex ferenda, while the second restricts its vision to the lex lata. This tension has played out throughout the history of the ILC's work. ${ }^{\text {II }}$

The ILC typically initiates a work programme on a closely defined issue or question of international law. It then devotes years to the development of draft reports in which it provides its view of the law on the issue or question. These studies can result in a final outcome report to the General Assembly, which can take the form of "Draft Articles", i.e. provisions which the ILC recommends to the General Assembly as fit for inclusion in a treaty on the subject. ${ }^{\mathrm{I} 2}$ Particularly in my role as faculty advisor to my Law School's Jessup International Law Moot Court team, I am regularly called upon to advise students on how they should treat the final outcome reports of the ILC for purposes of their advocacy, both in their written memorials and in their oral presentations. I typically tell them what I think most other international law professors tell them as a matter of orthodoxy, which is that ILC final outcome reports are generally accepted as correct statements of existing CIL-i.e. that the ILC essentially functions as another law identifying mechanism, along with international courts.

Io. See Sean MURPHY, "Codification, Progressive Development, or Scholarly Analysis? The Art of Packaging the ILC's Work Product” in Maurizio RAGAZZI, ed., The Responsibility of International Organizations: Essays in Memory of Sir Ian Brownlie (Leiden: Brill, 2013); Donald M. MCRAE, "The Work of the International Law Commission, 2007-20II: Progress and Prospects” (20I2) IO6 American Journal of International Law 322.

I I. See e.g. Robert JENNINGS, "Recent Developments in the International Law Commission: Its Relation to the Sources of International Law" (I964) I 3 International and Comparative Law Quarterly 385 ; Donald M. MCRAE, "The International Law Commission: Codification and Progressive Development After Forty Years” (I987) 25 Canadian Yearbook of International Law 355.

I 2. However, see Jacob K. COGAN, “The Changing Form of the International Law Commission's Work" (20I4) IO8 AJIL Unbound 4. 
What I don't typically tell them (so as not to confuse them) is that, while some of the ILC's final outcome reports have indeed been received by the international legal community as accurate and useful explications of existing customary international law, others have been widely criticized as stretching the existing evidence of state practice and opinio juris to untenable degrees in order to find support for more progressive or aspirational statements about law in the area of study. ${ }^{13}$ Just to make the issue more complex, some final outcome reports have been regarded as including both accurately descriptive statements of the lex lata, and rather weakly supported statements of the lex ferenda. ${ }^{\mathrm{I}}$ Again, this is no accident. The ILC is mandated to engage in both exercises -i.e. the identification of existing law and the support of legal development. Sometimes they choose to engage in both exercises within the same report on the law.

When forced to ask myself the question, then, of whether the reports of the ILC can be counted on to provide an authoritative source for the identification and determination of rules of CIL, I have to answer in the negative, as a general proposition. This is, again, due to the ILC's explicit mandate, and track record, of engagement in both descriptive and normative reporting. It is also due to the relative opacity of the ILC's deliberations and methodology for identifying and weighing evidence relating to CIL, and the well-documented politicization of some of the ILC's work programmes. ${ }^{\mathrm{I} 5}$ This is not, of course, to say that none of the ILC's work products should be relied upon as accurate statements of existing CIL. Rather, that the fact alone that an assertion about the current content of CIL is contained in an ILC final outcome document is not itself sufficient for that assertion to be relied upon as accurate.

\section{Academics}

Article 38 of the Statute of the ICJ actually lists academics, along with international courts, as law determining mechanisms-essentially as finders and explicators of the law. As it states:

The Court, whose function is to decide in accordance with international law such disputes as are submitted to it, shall apply ... judicial decisions and the teachings of the most highly qualified publicists of the various nations, as subsidiary means for the determination of rules of law.

In my experience in the international legal academy, I have seen examples of work in which the author or authors have made a truly good faith effort to look comprehensively and systematically for evidence of state practice and opinio juris on some issue of law, and have rigorously applied this evidence to the two-element formula as the orthodoxy requires. ${ }^{16}$ But frankly, I've seen many more examples of work in which the

\footnotetext{
I3. See Jose E. ALVAREZ, International Organizations as Lawmakers (Oxford: Oxford University Press, 2006) at 304-I6.

I4. Ibid.

15. See B.G. RAMCHARAN, The International Law Commission: Its Approach to the Codification and Progressive Development of International Law (Leiden: Nijhoff, I977) at 3I-5.

I6. See e.g. Arthur Mark WEISBURD, Use of Force: The Practice of States Since World War II (University Park, PA: Penn State University Press, I997).
} 
author has selectively picked from the available information relatively few pieces of evidence, which they often double-count as both state practice and opinio juris, before basing some assertion about the content of CIL upon them. Very frequently this involves selective reference to resolutions of the UN General Assembly or other international deliberative body, reports of working groups set up by some international organization or other, cherry-picked statements by state officials, and circular reliance on the assertions of other scholars. Often no real attempt is made to provide a systematic or comprehensive assessment of the evidence of state practice or opinio juris by states on the topic. Once a number of these carefully selected pieces of evidence has been recited, an assertion is then made about them signifying an existing, or emerging, rule of CIL. And just to put my cards fully on the table, I have been guilty of this methodological malpractice myself. ${ }^{17}$ I suspect most of my colleagues in the academy could, if they are honest, say the same.

\section{Why Can None of Us Do this Right?}

So what explains the fact that neither courts nor the ILC nor academics can be relied upon to do a comprehensive, rigorous, systematic analysis of the available evidence of state practice and opinio juris, and carefully and methodically apply that evidence to the two-element test for determining the existence of CIL, as we all teach our students to do every year during the second day of our international law courses?

I think that there are a number of reasons for this. The first group of reasons is grounded in the practicalities of this exercise. There are currently 195 independent sovereign states in the world. Let's say you wanted to know whether there is currently a rule of customary law allowing an exception from UN Charter Article 2(4) for humanitarian intervention. Does that mean you actually have to look back over several decades of diplomatic practice and evidence of the conduct and statements of all I95 states to see what they have done and said about the idea of such a principle? If you approach the two-element test for CIL as an inductive process, through which one collects a comprehensive data set and draws conclusions about whether the evidence satisfies each of the elements from that data set, then the orthodox theory of CIL determination would seem to require just that. That is a tall order, whether you are talking about a court, the ILC, or an academic.

And even if you did gather together such a comprehensive data set, how would you know how to code each statement or action by each state in a way that would create a sensible metric for determining what each data point means in comparison to other data points? Assuming that there are complex nuances in how states have acted and spoken about the idea in question, how do you determine whether there is even some unified definition of the principle they are all acting and thinking about, and if so what it is?

I7. See Daniel H. JOYNER, "United Nations Counter-proliferation Sanctions and International Law" in Larissa VAN DEN HERIK, ed., Research Handbook on UN Sanctions and International Law (Cheltenham: Edward Elgar Publishing, 20I7). I am referring to the process by which I asserted the existence of a rule of CIL prohibiting coercive economic sanctions, on pages II 5-I 6 . 
And again, even if you could gather together all of this data, code them properly, put them into a matrix and determine a definition of the principle in question, you're still left with the questions my brighter students ask, e.g. How much and what kind of state practice is necessary to satisfy the state practice element? Is there a required duration of practice? Does the practice of some states matter more than others? What does the silence of one or more states mean? What kinds of evidence and how much of it is required to satisfy the opinio juris element? Frankly, we just do not know the answers to these questions. There is certainly no dearth of opinion about them in the scholarly literature, but in the end we have no authoritative answers. Again, the law-identifying agencies that we might look to for such authoritative answers-i.e. international courts and the ILC-have never given them to us, either by their words or their practice. So the aspiring identifier of CIL is really left on their own to come up with some way to persuasively answer these questions, when applying the data set to the elements.

I have seen a few attempts at such a comprehensive, rigorous approach to gathering data and applying it to the two-element formula. The International Committee on the Red Cross's 2005 study on Customary International Humanitarian Law comes immediately to mind, though that study has received a good deal of methodological criticism itself. ${ }^{\mathrm{I} 8}$ The point is, though, that even if such studies are attempted occasionally by NGOs or academics, by far and away the most common practice for international courts, the ILC, and academics does not involve this kind of thorough and systematic review of evidence, and painstaking application of the data to the two elements in a thoughtful, systematic way, in order to produce a persuasive determination of the existence or not of a rule of CIL. It's just too big a task for most of us to think about taking on, and one for which, frankly, most of us simply don't have the resources or skill set to take on.

But there are other reasons for our collective failure to do CIL identification in the way in which we teach our students it should be done, quite apart from those grounded in practicalities and the limits of our wills and abilities. What a number of scholars have realized, and which I find quite persuasive, is that all of us-international courts, the ILC, and academics - in fact use our corrupted methodologies for determining the presence of CIL in order to serve our own instrumentalist ends. ${ }^{\text {I9 }}$ I noted above Stefan Talmon's observation that international courts frequently assert the existence of principles of CIL, with little evidentiary or methodological basis, in order to fill perceived gaps in the law, and to avoid a non liquet. ${ }^{20}$ This is essentially an instrumentalist purpose for the court, allowing it to avoid the appearance of uselessness through inability to decide the questions before it. And, I also noted previously, the ILC's mandate in its founding statute to not only codify existing law but also contribute to its progressive development. And academics—well we've all got ideas and new directions

\footnotetext{
I8. See Elizabeth WILMSHURST and Susan BREAU, eds., Perspectives on the ICRC Study of Customary International Humanitarian Law (London: Chatham House, 2007).

I9. See Helfer and Wuerth, supra note I; d'Aspremont, "Expansionism and the Sources of International Human Rights Law”, supra note I; d'Aspremont, "The Decay of Modern Customary International Law in Spite of Scholarly Heroism", supra note I.

20. See Talmon, supra note I.
} 
for legal development that we would like to find support for among the evidences of customary law. Again, I confess I've done this myself.

All of us would-be CIL identifiers, it turns out, use our conveniently short-cut methodologies for determining CIL, in order to expand the substantive frontiers of what is generally accepted as international law, for our own instrumentalist reasons. We basically take advantage of the methodological mess that has become so firmly institutionalized by the previous efforts of CIL identifiers, to make equally messy yet convenient arguments for normative evolution through CIL in directions that suit our particular goals. And while this phenomenon almost certainly occurs across the substantive areas of international law, it has been persuasively argued to be most pronounced in the three substantive areas that have been collectively referred to as constituting the "humanization trend" in international law post-World War II. ${ }^{2 \text { I }}$ These areas are international humanitarian law [IHL], international human rights law [IHRL], and international criminal law [ICL].

The "humanization" thesis holds that these three areas developed in the post-war period as a reaction to the horrors of the war, and the loss of civilian life in particular. They were seen as a needed course correction to the exclusive state-centricism of classical international law. The principles of justice and humanism that underlay this movement in law creation, understandably led identifiers of CIL over the years to exert efforts to stretch the bounds of legal obligation further, at times, than states had explicitly accepted through treaty law. As Jean D'Aspremont has observed in the context of IHRL:

In IHRL scholarship and practice, customary international law has proved the most popular law ascertainment instrument when it comes to stretching the scope of IHRL and "discovering" new rules for the protection of individuals. It is as if anything that cannot be supported by treaties and which is deemed desirable can, with a bit of effort and creativity, be found in customary law. The reason for the success of custom is not difficult to fathom. Its greater departure from formal modes of legal reasoning provides a less constrained argumentative space and this is why it has been deemed "irresistible" for human rights lawyers. ${ }^{22}$

In the ICL context, the expansionist use of CIL to justify obligations exceeding what states had agreed to in treaties goes all the way back to the area's genesis at the end of World War II. As is well known, in the Nuremberg war crimes trials, quite tenuous arguments were employed by allied lawyers and judges to support the existence of obligations of CIL that applied to individuals directly, and that overcame what were quite well accepted legal principles at the time, such as the defence of superior orders and the ancient criminal law maxim nullem crimen sine lege. ${ }^{23}$ This instrumentalist use

2I. See e.g. Monica HAKIMI, “Custom's Method and Process: Lessons from International Humanitarian Law” in Bradley, supra note I.

22. d'Aspremont, "Expansionism and the Sources of International Human Rights Law", supra note I.

23. See Antonio CASSESE and Paolo GAETA, eds, Cassese's International Criminal Law, 2nd ed. (Oxford: Oxford University Press, 2008) at I05-7. 
of CIL for expansionist purposes has been well documented to have continued through the I990s establishment of ad hoc international criminal courts. ${ }^{24}$

Similarly well documented is the use of expansionist arguments grounded in CIL to "fix" perceived problems with $\mathrm{IHL}^{25}$. The prime example of this is the use of arguments based in CIL to extend the obligations of the I949 Geneva Conventions-which themselves textually limit their application to the "High Contracting Parties"-beyond the States Parties to the treaties, to apply also to non-state organized armed groups participating in both international and non-international armed conflict. ${ }^{26}$

In each of these three substantive areas of international law, again, the motivation for this instrumentalist expansionism through CIL is grounded in a desire to extend human rights and humanitarian protections to particularly vulnerable populationsan essentially laudable aim. And the substantive law which has been "found" through the methodological fudging of the evidence of CIL has, arguably, produced a useful result in the development of the international legal system. However, the means by which this end has been accomplished cause heartburn to a formalist like myself.

The particular methodological tool that has been used in almost all instances of instrumentalist expansion of CIL, including those in the "humanization" areas, has been the accordance of disproportionate weight to one of the two CIL identification elements-the opinio juris element. This has been termed the "modern approach" to CIL identification. ${ }^{27}$ The idea behind the modern approach is that focusing on the subjective element-i.e. what states think is or should be the law-is preferable because not all states have the capacity to engage in significant practice across the substantive areas of international law, and all states should be able to meaningfully participate in the process of CIL creation through their manifestations of opinio juris. This method, it is argued, allows for the more expeditious development of law, and is particularly important in the "humanization" areas of law in which treaty-making can be a painfully slow process, subject to principled compromise and the entry of reservations by states limiting application.

There has been a rich debate in scholarly sources about the idea of focusing on opinio juris and giving that element primacy of consideration when engaging in CIL identification. ${ }^{28}$ My own view of this debate has been to be largely persuaded by the arguments in favour of the modern approach, as I think it tends to level the playing field among states at varying levels of development and capacity to act internationally. I see no inherent theoretical problem with focusing on states' manifested, subjective view of what international law is and should be. In my view, this concept is no different from that underpinning the idea of legislative action in domestic legal systems. However, while in theory a focus on the subjective element of the CIL identification formula is not

\footnotetext{
24. See generally Nobuo HAYASHI and Cecilia BAILLIET, eds., The Legitimacy of International Criminal Tribunals (Cambridge: Cambridge University Press, 20I7).

25. See Hakimi, supra note 2 I.

26. See Daragh MURRAY, "How International Humanitarian Law Treaties Bind Non-State Armed Groups" (2015) 20 Journal of Conflict \& Security Law IOI.

27. Anthea ROBERTS, “Traditional and Modern Approaches to Customary International Law: A Reconciliation" (200I) 95 American Journal of International Law 757.

28. See Blutman, supra note I.
} 
inherently problematic, what is problematic is that the international legal system is simply not currently institutionally structured to support such a methodological approach to law creation. In short, there is no international legislative institution, or agreed legislative process in the international legal system, that could facilitate the identification of CIL on the basis of states' manifestations of subjective will. The most obvious candidate for such an institution is the United Nations General Assembly. However, the role and rules of procedure of the General Assembly are clearly laid out in the UN Charter, and do not mandate or support a legislative function.

Without an institutionalized or agreed process for the creation of CIL through the subjective manifestations of states, the idea of basing CIL identification primarily on the opinio juris element is far too susceptible to methodological hijacking for instrumentalist purposes. Again, a few recitations of the provisions of General Assembly resolutions, a UN Human Rights Committee working group report, and a paper by a scholar reporting strong state support for a principle, and voilà!, we have a new rule of CIL.

Again, even though much of the instrumentalist expansion of international law through methodologically compromised assertions of CIL, particularly in the "humanization" areas, has produced accepted rules of law that I, and I think most international lawyers, support substantively as useful and positive developments in the international legal system, for those like myself who are essentially formalists in their approach to international law, the methods by which these rules have been created are very troubling. This is because they run counter to a fundamental principle that I would contend remains essential to the modern positivist conception of the international legal system, i.e. that the sources of international law are essentially based, even if imperfectly, upon the consent of states to be bound to international legal obligation. ${ }^{29}$ When legal obligations or rights are created without a sound basis in the consent of states to be bound, however well intentioned that normative evolution is, this foundational principle is compromised. This in turn decreases states' confidence in international law and its foundations in respect for their sovereignty and independence. ${ }^{30}$ So while in the short term the creation of obligations which expand the legal protections provided by IHRL, for example, may seem worth the instrumentalist use of compromised CIL identification methodology, from a long-term systemic perspective this use of CIL in a way that divorces its creation from the consent of states to be bound, risks decreasing the perceived legitimacy of the international legal system itself.

In summary, it has become increasingly clear that international courts, the ILC, and academics all typically go about the exercise of CIL identification in a methodologically compromised manner. We do this not only, or even primarily, due to practical difficulties, though those do exist. Rather, we frequently do it this way for instrumentalist reasons, as a useful means for arguing for the expansion or evolution of international

29. See generally Malcolm N. SHAW, International Law, 6th ed. (Cambridge: Cambridge University Press, 2008) at 9-II.

30. See Sienho YEE, “A Reply to Sir Michael Wood's Response to AALCOIEG's Work and My Report on the ILC Project on Identification of Customary International Law” (2016) I 5 Chinese Journal of International Law 33 . 
legal rules in directions that suit our particular aims. This is why I now presumptively distrust any statement about what is or is not a rule of CIL from any of these CIL identifying agencies. And it's why I've just simply stopped believing in CIL as a supportable source for the creation of international legal obligation.

\section{CIL'S DEFENDERS}

I mentioned previously the ongoing ILC work programme on the topic of the identification of CIL. That programme is now in its fifth year, with four draft reports produced by the Special Rapporteur, Sir Michael Wood. In speeches he has given during his tenure, and in a few pieces he has published over this time, he has mounted a spirited defence of the orthodox approach to the identification of CIL, which he has similarly written into his ILC draft reports. ${ }^{3 \mathrm{I}}$

According to Sir Michael, the recent proliferation of scholarly work criticizing CIL and the methodology of its identification by courts is neither new nor particularly novel. He points to moments of intense criticism of CIL going back to the nineteenth century, resuming in the I920s, and again in the post-colonial era. Notwithstanding these historical critiques, which he considers to be largely rehashed by today's scholars, he maintains: "Far from ceasing to be influential, customary international law has all along retained a central place in international legal discourse, as it continues to do at present." 32

Sir Michael's primary argument in response to scholarly criticism of the methodology employed by CIL identifiers is that, while academics may continue to assert theoretical problems with this methodology and the resulting substantive rules, this has had no effect on the day-to-day use and usefulness of CIL in practice among state officials and before courts. As he writes:

From legal opinions by government legal advisers to diplomatic correspondence and official statements by states, custom features regularly in the everyday practice of international law. It is frequently invoked before international courts and tribunals, particularly in interstate disputes ... Despite the academic controversies surrounding customary international law and the difficulty of some authors to accept a source of law that by its very nature defies exact definition, the theoretical torment that accompanies custom in the books simply does not impede it in action. The question of proof, in particular, "does not present as much difficulty as the writers have anticipated", and a settled methodology for ascertaining the existence of a rule of customary international law ... is indeed observable in practice. ${ }^{33}$

3I. See Wood, supra note 3; Michael WOOD, "The Present Position Within the ILC on the topic 'Identification of Customary International Law': in Partial Response to Sienho Yee" (2016) I 5 Chinese Journal of International Law 3; Michael WOOD and Omri SENDER, "Identifying the Rules for Identifying Customary International Law: Response from Michael Wood and Omri Sender” (2015) ro8 AJIL Unbound I96; Omri SENDER and Michael WOOD, "The International Court of Justice and Customary International Law: A Reply to Stefan Talmon” EJILTalk! (30 November 201 5), online: EJILTalk! < https:// www.ejiltalk.org/the-international-court-of-justice-and-customary-international-law-a-reply-to-stefantalmon/>.

32. Wood, supra note 3 at 363 .

33. Ibid. at $365-6$. 
Clearly Sir Michael is not alone in being less than impressed by the recent flurry of academic commentary decrying CIL identification techniques. The ILC has consistently supported his reports which recite the orthodox approach to CIL identification, complete with the two-element formula.

At essence, Sir Michael's argument appears to be that, notwithstanding the theoretical and methodological problems asserted by academics, government officials and courts in practice continue to regularly rely on arguments based in CIL, and are generally unconcerned about the dash of methodological sophistry typically necessary to maintain those arguments. This is because they find CIL important and useful for, inter alia, filling gaps in existing treaty law, for governing relations between non-parties to treaties or when jurisdictional limits apply to relevant treaties, and for providing answers in cases where there is no clear answer found in treaty law.

However, I would respectfully suggest that Sir Michael's arguments are limited in their power to rebut the academic critics of CIL identification because they, quite consciously, do not address these critics' arguments head-on. Rather, they sidestep the criticisms, and avoid substantive engagement with them, by claiming that the academics' concerns do not, in the end, matter because the practitioners of international law (of which he was himself one) simply aren't bothered by them, and get along quite well with their use of CIL in their daily work anyway, thank you very much. This is a bit like my doctor telling me that I shouldn't consume chocolate and pasta because they're bad for my health, to which my response is that I don't see any problems with my health so why should I care what my doctor says? I quite enjoy eating chocolate and pasta, have done so for many years, and plan to continue doing so without regard to this advice. But my disregard of my doctor's advice doesn't make that advice wrong. I'm just choosing to ignore it. And I'm putting my whole physical system at risk of collapse by doing so.

Sir Michael's argument that CIL is useful in many ways to courts and state officials also does not effectively rebut the theoretical and methodological scholarly assaults on CIL identification. If anything, it actually supports them by confirming the very instrumentalist purposes that these scholars have argued to be underlying much of the methodological mess of CIL identification. The fact of the usefulness of CIL per se says nothing about the soundness of modern approaches to CIL identification, and their implications for perceptions of the credibility of the international legal system.

\section{CONCLUSION}

So again, I think there is a big problem here. The problem is that the agencies that are looked to as identifiers of CIL-international courts, the ILC, and academics-have been demonstrated to typically go about that exercise in methodologically bankrupt ways. And we don't just do it because we are lazy or incompetent, we do it so that we can use the resulting assertions of CIL obligations in instrumentalist ways, typically to expand international law to apply in areas where states have not given their explicit consent to be bound through agreed treaty text. The asserted rules of CIL which the short-cut methodologies of identification create, are therefore of low credibility in the 
eyes of states, who are understandably reluctant to have judges and academics creating new legal obligations for them.

This problem is so difficult to address because it is so institutionally entrenched. Courts and the ILC and many academics have every reason to continue to support the orthodox approach to CIL identification, which is so susceptible to this methodological mischief, because it serves their instrumentalist purposes. The ILC's ongoing study on this topic, which will almost certainly provide yet another reaffirmation of the orthodox approach, will only further institutionalize the problem.

Again, my problem is not with CIL itself as a source of law. In a theoretical sense, I have no problem with the idea that states can collectively make law that governs their interactions with each other, through an evolving process that is not necessarily written down in one law-making moment. Particularly under the modern approach that places emphasis and priority upon opinio juris, states can manifest their recognition of an obligation, and their consent to be bound thereby, through their subjective statements of legal understanding.

The problem is that we simply do not currently have a structural framework within the international legal system that can support this method of law creation in a manner that satisfies concerns about objectivity and empirical verifiability of that positivistic manifestation of affirmation and consent. And without this institutional structure, the black magic that stands in for identification of CIL in practice undermines the credibility of every assertion of CIL. It also, by extension, undermines the credibility of the international legal system itself.

In order for CIL to survive as a supportable source of international legal obligation, we need to create such a system structure for the objective manifestation and empirical verifiability of positive manifestations of affirmation and consent to be bound by states, resulting in the identification of CIL obligations. This structure must have in place an agreed set of rules and procedures for how this is to happen. Exactly what this institutional structure should look like, I don't know, and space constraints here won't allow for a considered proposal.

But we have to do something. Because for me, and I think for an increasing number of international lawyers, the more we understand about the problems presented by the modern practice of identifying and asserting CIL, the more we will conclude that if CIL were Tinkerbell she'd be dead now. We just don't believe in her any more. 